\title{
HADITS TARBAWI TENTANG POTENSI ANAK ( FITRAH )
}

Oleh: Rubini

Dosen STAIMS Yogyakarta

\begin{abstract}
Two hadiths about the nature narrated by Imam Bukhari and Imam Ahmad bin Hanbal is an authentic hadiths. Having already qualified - requisites the terms of validity of a tradition that continued sanadnya, All the narrators in the sanad are fair and dhabith, in the sanad avoid Syudzudz (irregularities) and 'illat (disability). Nature is the potential to be good and bad at the same time becomes, the potential to be a Muslim and to be idolatrous. Put simply, nature is defined by the potential for religious, is also the potential for no religion. Education is a tool for maintain fithrah khalqiyyah and means to sharpen and develop fithrah munazzalah so as to implement diversity and good morality. Parents have the responsibility to develop according to their nature, are responsible for their children's education. Education appropriate measures must be taken by parents is education monotheism, morality education, education, prayer, education Amar Ma'ruf Nahi Munkar, education fortitude and patience.
\end{abstract}

\section{Abstrak}

Dua hadits yang tentang fitrah yang diriwayatkan oleh Imam Bukhari dan Imam Ahmad bin Hanbal adalah merupakan hadits yang shahih. Karena telah memenuhi syarat - syarat keshahihan suatu hadis yaitu Sanadnya bersambung, Seluruh perawi dalam sanad tersebut bersifat adil dan dhabith, dalam sanad tersebut terhindar dari Syudzudz(kejanggalan) dan 'illat(cacat). Fitrah adalah potensi-potensi untuk menjadi baik dan sekaligus menjadi buruk, potensi untuk menjadi muslim dan untuk menjadi musyrik. Secara sederhana, fitrah di sini diartikan dengan potensi untuk beragama, juga potensi untuk tidak beragama. Pendidikan merupakan media untuk mempertahankan fithrah khalqiyyah dan sarana untuk mengasah dan menumbuhkembangkan fithrah munazzalah sehingga mampu mengimplementasikan keberagaman dan moralitas yang baik. Orang tua mempunyai tanggung jawab kepada anaknya berkembang sesuai fitrahnya, 
bertanggung jawab terhadap pendidikan anaknya. Langkah pendidikan yang tepat harus ditempuh oleh orang tua adalah pendidikan ketauhidan, pendidikan Akhlaq, pendidikan Sholat, pendidikan Amar Ma'ruf Nahi Mungkar, pendidikan ketabahan dan kesabaran.

\section{A. Pendahuluan}

Hakekatnya manusia adalah makhluk yang dapat dididik dan mendidik (belajar-mengajar), dan dapat dipengaruhi serta mempengaruhi. Manusia bukanlah makhluk yang selalu pasif yang hanya dapat menerima saja dan juga manusia bukan makhluk agresif yaitu yang dapat memberikan dan mempengaruhi, tetap tidak dapat dipengaruhi oleh keadaan.

Secara nyata, manusia memang terikat dengan alam lingkungan yang dapat mengubah atau mempengaruhinya. Dengan fitrah khalqiyah dan fitrah munazzalah yaitu berupa potensi-potensi internal yang dimiliki manusia, ia memiliki peluang untuk mengubah alam lingkungannya sesuai yang dikehendakinya. Ini berarti bahwa manusia dalam perkembangannya memiliki potensi bawaan dan pengaruh lingkungan. Dalam khasanah filsafat pendidikan Barat dikenal adanya teori perkembangan manusia, yaitu: empirisme, nativisme, dan konvergensi.

Empirisme yang dipelopori oleh John Locke menyatakan bahwa perkembangan pribadi manusia ditentukan oleh faktorfaktor alam lingkungan, termasuk pendidikan. Ibaratnya adalah setiap individu manusia lahir bagaikan kertas putih yang siap diberi warna atau tulisan oleh faktor lingkungan. Teori ini dikenal dengan teori tabularasa. Bagi Locke, faktor lingkungan yang 
memiliki kontribusi besar terhadap pembentukan pribadi seseorang 19 .

Nativisme yang dipelopori Arthur Schopenhauer (17881860) menyatakan bahwa perkembangan pribadi hanya ditentukan oleh bawaan (kemampuan dasar), bakat serta faktor dalam yang bersifat kodrati. Faktor bawaan ini tidak bisa diubah oleh pengaruh lingkungan atau pendidikan. Apapun usaha pendidikan yang bertujuan membentuk kepribadian tidak dapat menggapai tujuan yang diinginkankan tanpa dukungan faktor bawaan. ${ }^{20}$

Teori konvergensi yang diusung oleh William Stern (18711938) menyatakan bahwa perkembangan manusia berlangsung atas pengaruh dari faktor bakat/kemampuan dasar dan faktor lingkungan, termasuk pendidikan. Jadi proses perkembangan manusia merupakan hasil kerjasama antara faktor dasar (bawaan) dan alam lingkungan. ${ }^{21}$

Selain tiga teori tersebut, dikenal pula konsep "dosa warisan" di kalangan umat Nasrani yang menyatakan bahwa manusia lahir membawa seperangkat dosa waris. Yang jadi pertanyaan adalah bagaimana dengan Islam, apakah Islam memiliki teori tentang perkembangan manusia?

Dalam khasanah Islam dikenal teori tentang hakikat manusia yang tercermin dalam teori fitrah. Secara lebih lanjut penulis akan membahas hadis tentang fitrah dilihat dari sanad dan matannya, kritik sanad dan kritik matan, serta pemahaman tentang hadis tersebut.

19 I.R. Poedjowijatma, Manusia Dengan Alamnya (Filsafat Manusia), (Jakarta : Bina Aksara, 1983), hlm. 56-76

20 Ibid 86

${ }^{21}$ Ibid 90 
Rubini : Hadits Tarbawi Tentang Potensi Anak (Fitrah)

\section{B. Pembahasan}

Hadis tentang fitrah paling tidak tercantum dalam empat kitab hadis standar yang disusun oleh para imam hadis terkenal, yakni: Imam al-Bukhâri, Imam Muslim, Abû Dâwud, dan alTurmudzi, serta terdapat dalam kitab karya Ahmad bin Hanbal. Meskipun memiliki matan (baca: redaksi) hadis yang beragam, namun secara substantif memiliki pengertian yang sama. Berikut ini akan disajikan 2 (dua) redaksi hadis yaitu :

1. Al - Bukhari

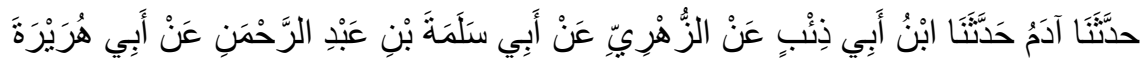

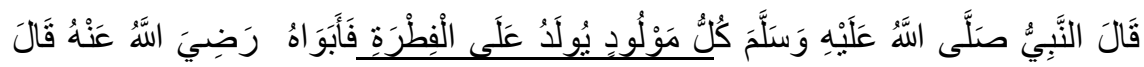

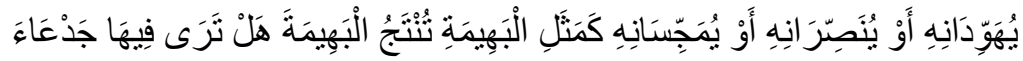

Telah menceritakan kepada kami Adam telah menceritakan kepada kami Ibnu Abu Dza'bin dari Az Zuhriy dari Abu Salamah bin 'Abdurrahman dari Abu Hurairah radliallahu 'anhu berkata; Nabi Shallallahu'alaihiwasallam bersabda: "Setiap anak dilahirkan dalam keadaan fithrah. Kemudian kedua orang tuanyalah yang akan menjadikan anak itu menjadi Yahudi, Nashrani atau Majusi sebagaimana binatang ternak yang melahirkan binatang ternak dengan sempurna. Apakah kalian melihat ada cacat padanya (HR. Bukhori. No.1296)

2. Ahmad bin Hambal

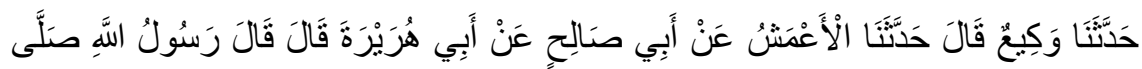

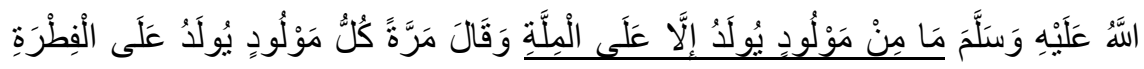

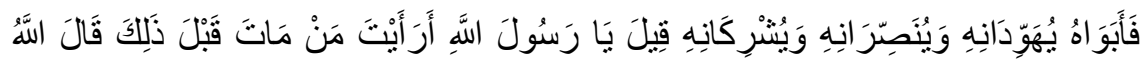

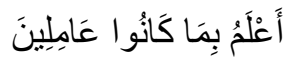


Telah menceritakan kepada kami Waki', dia berkata; telah menceritakan kepada kami Al A'masy dari Abu Shalih dari Abu Hurairah, dia berkata; Rasulullah shallallahu 'alaihi wasallam bersabda: "Tidak ada bayi yang dilahirkan kecuali di atas millah (agama Islam), -dan sesekali beliau bersabda: "Setiap bayi dilahirkan dalam keadaan fitrah, maka bapaknyalah yang menjadikannya Yahudi, atau Nasrani atau Musyrik, " maka ditanyakanlah kepada beliau; "Wahai Rasulullah, bagaimana pendapatmu bagi mereka yang meninggal sebelum umur baligh?" maka beliau bersabda: "Allah lebih tahu dengan yang mereka kerjakan (HR. Ahmad. No: 9851$)^{22}$

Skema Sanad disajikan dalam bentuk tabel :

\begin{tabular}{|l|l|l|}
\hline No. & Nama Perawi & Keterangan \\
\hline 1. & Abu Hurairah & Perawi I \\
\hline 2. & Abu Musalamah bin Abdur Rahman & Perawi II \\
\hline 3. & Az-Zuhriy & Perawi III \\
\hline 4. & Ibnu Abi Dzibin & Perawi IV \\
\hline 5. & Adam & Perawi V \\
\hline 6. & Al Bukhori & Mukharrij \\
\hline
\end{tabular}

\begin{tabular}{|l|l|l|}
\hline No. & Nama Perawi & Keterangan \\
\hline 1. & Abu Hurairah & Perawi I \\
\hline 2. & Abu Shalih & Perawi II \\
\hline 3. & Al A'mas & Perawi III \\
\hline 4. & Waqi' & Perawi IV \\
\hline 5. & Ahmad bin Hanbal & Mukharrij \\
\hline
\end{tabular}

22 Kutubut Tis'ah CD room 
Rubini : Hadits Tarbawi Tentang Potensi Anak (Fitrah)

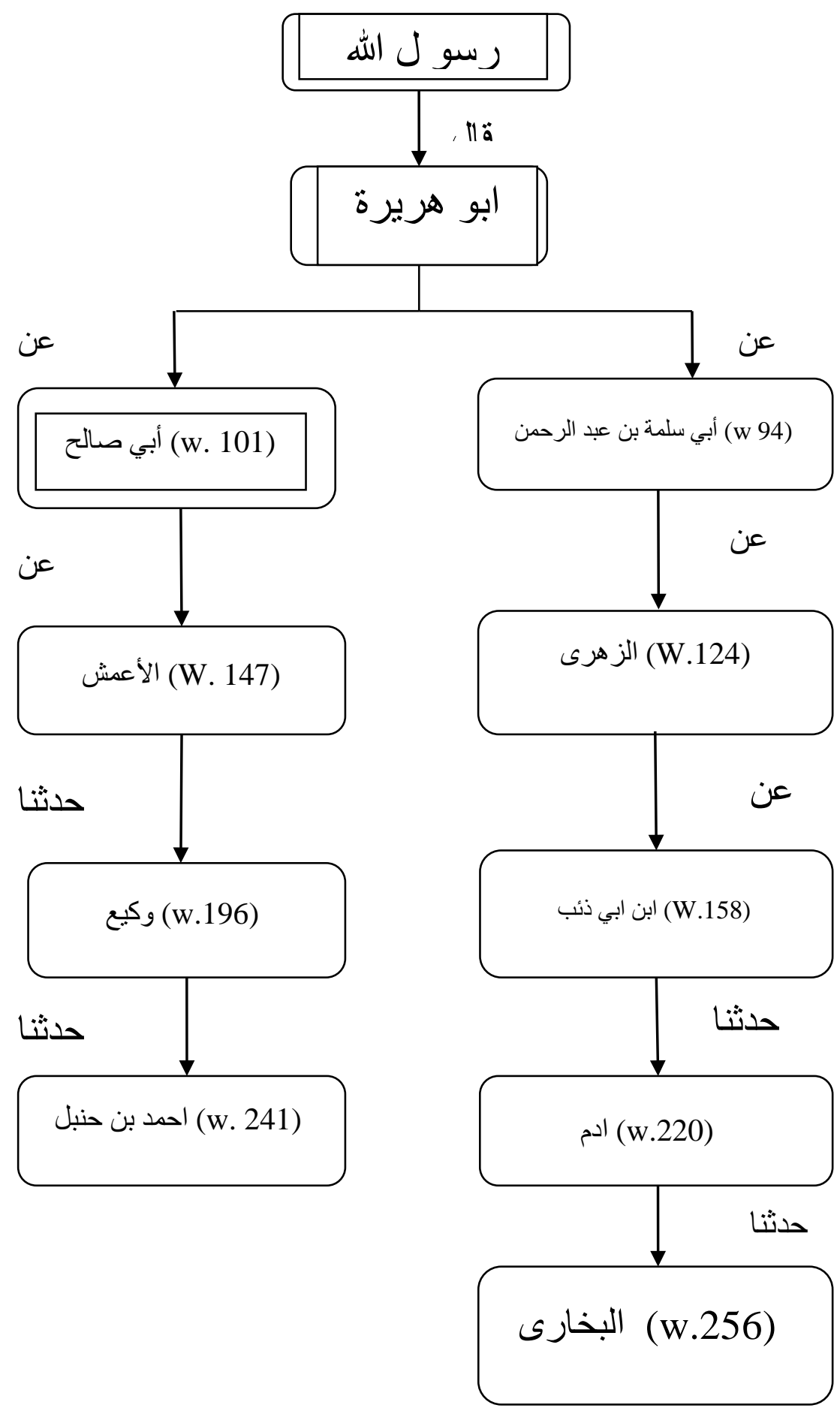


Menurut Ibn Shalah (wafat $643 \mathrm{H}$ ), salah seorang ulama hadis al-muta'akhirin yang memiliki banyak pengaruh dikalangan ulama hadis sezamannya dan sesudahnya, telah memberikan definisi hadits sahih adalah

1. Hadis yang bersambung sanadnya( sampai kepada nabi)

2. Diriwayatkan oleh periwayat yang adil dan dhabith sampai akhir sanad

3. Di dalam hadis itu tidak terdapat kejanggalan (syudzudz) dan cacat('illat). 23

Untuk penelitian sanad ini, kami akan membahas kedua hadis tersebut.

1. $\mathrm{Al}$ - Bukhari (Wafat $256 \mathrm{H}$ )

Nama lengkapnya adalah Muhammad bin Isma'il bin Ibrahim bin al Mughirah bin Bardizbah.Nama panggilannya/ Kuniyah adalah Abu Abdullah. Sedangkan nasab beliau adalah Al Ju'fi; nisabah Al Ju'fi adalah nisbah arabiyyah. Faktor penyebabnya adalah, bahwasanya al Mughirah kakek Bukhari yang kedua masuk Islam berkat bimbingan dari Al Yaman Al Ju'fi. Maka nisbah beliau kepada Al Ju'fi adalah nisbah perwalian. Al Bukhari yang merupakan nisbah kepada negri Imam Bukhari dilahirkan di Bukhara pada hari Jum'at setelah shalat Jum'at 13 Syawwal 194 H.

Diantara guru-guru beliau Imam Bukhari berjumpa dengan sekelompok kalangan atba'ut tabi'in muda, dan beliau meriwayatkan hadits dari mereka, sebagaimana beliau juga meriwayatkan dengan jumlah yang sangat besar dari kalangan selain mereka. Dalam masalah ini beliau bertutur; '

23 Syuhudi Ismail, Kaedah Kesahihan Sanad Hadits, (Jakarta : Bulan Bintang, 1988), hlm. 109 
aku telah menulis dari sekitar seribu delapan puluh jiwa yang semuanya dari kalangan ahlul hadits.Guru-guru imam Bukhari terkemuka yang telah beliau riwayatkan haditsnya; Adam bin Abi Iyas, Abu 'Ashim An Nabil Makki bin Ibrahim, Muhammad bin 'Isa bin Ath Thabba', Ubaidullah bin Musa, Muhammad bin Salam Al Baikandi, Ahmad bin Hambal, Ishaq bin Manshur, Khallad bin Yahya bin Shafwan,Ayyub bin Sulaiman bin Bilal,Ahmad bin Isykab, dan masih banyak lagi. Murid-murid beliau Al Hafidz Shalih Jazzarah berkata; Muhammad bin Isma'il duduk mengajar di Baghdad, dan aku memintanya untuk mendektekan (hadits) kepadaku, maka berkerumunlah orang-orang kepadanya lebih dari dua puluh ribu orang.

Maka tidaklah mengherankan kalau pengaruh dari majelisnya tersebut menciptakan kelompok tokoh-tokoh yang cerdas yang meniti manhaj, dintara mereka itu adalah;Al imam Abu al Husain Muslim bin al Hajjaj an Naisaburi (204261), penulis buku shahih Muslim yang terkenal Al Imam Abu 'Isa At Tirmizi (210-279) penulis buku sunan At Tirmidzi yang terkenal, Al Imam Shalih bin Muhammad (205-293)Al Imam Abu Bakr bin Muhammad bin Ishaq bin Khuzaimah (223-311), penulis buku shahih Ibnu Khuzaimah, Al Imam Abu Al Fadhl Ahmad bin Salamah An Naisaburi (286), teman dekat imam Muslim, dan dia juga memiliki buku shahih seperti buku imam Muslim dan masih banyak lagi.

Persaksian para ulama terhadap beliau: Sangat banyak sekali para ulama yang memberikan kesaksian atas keilmuan imam Bukhari, diantara mereka ada yang dari kalangan gurugurunya dan teman-teman seperiode dengannya. Adapun 
periode setelah meninggalnya bukhari sampai saat ini, kedudukan imam Bukhari selalu bersemayam di dalam relung hati kaum muslimin, baik yang berkecimpung dalam masalah hadits, bahkan dari kalangan awwam kaum muslimin sekali pun memberikan persaksian atas keagungan beliau. Diantara para tokoh ulama yang memberikan persaksian terhadap beliau adalah;

a. Abu Bakar Ibnu Khuzaimah telah memberikan kesaksian terhadap Imam Bukhari dengan mengatakan: "Di kolong langit ini tidak ada orang yang lebih mengetahui hadits dari Muhammad bin Isma'il." 'Abdan bin 'Utsman Al Marwazi berkata; 'aku tidak pernah melihat dengan kedua mataku, seorang pemuda yang lebih mendapat bashirah dari pemuda ini.' Saat itu telunjuknya diarahkan kepada Bukhari.

b. Qutaibah bin Sa'id menuturkan; 'aku duduk bermajelis dengan para ahli fikih, orang-orang zuhud dan ahli ibadah, tetapi aku tidak pernah melihat semenjak aku dapat mencerna ilmu orng yang seperti Muhammad bin Isma'il. Dia adalah sosok pada zamannya seperti 'Umar di kalangan para sahabat. Dan dia berkata; ' kalau seandainya Muhammad bin Isma'il adalah seorang sahabat maka dia merupakan ayat.

c. Ahmad bin Hambal berkata; Khurasan tidak pernah melahirkan orang yang seperti Muhammad bin Isma'il.

d. Abu Bakar bin Abi Syaibah dan Ibnu Numair menuturkan; kami tidak pernah melihat orang yang seperti Muhammad bin Ism'ail . 
Rubini : Hadits Tarbawi Tentang Potensi Anak (Fitrah)

e. Abu Hatim ar-Razi berkata: "Khurasan belum pernah melahirkan seorang putra yang hafal hadits melebihi Muhammad bin Isma'il,Â juga belum pernah ada orang yang pergi dari kota tersebut menuju Irak yang melebihi kealimannya."

Diantara hasil karya Imam Bukhari adalah sebagai berikut:

1) Al Jami' as Sahih (Sahih Bukhari)

2) Al Adab al Mufrad.

3) At Tarikh ash Shaghir.

4) At Tarikh al Awsath.

5) At Tarikh al Kabir.

Imam Bukhari keluar menuju Samarkand, Tiba di Khartand, sebuah desa kecil sebelum Samarkand, ia singgah untuk mengunjungi beberapa familinya. Namun disana beliau jatuh sakit selama beberapa hari. Dan Akhirnya beliau meninggal pada hari sabtu tanggal 31 Agustus $870 \mathrm{M}(256 \mathrm{H})$ pada malam Idul Fitri dalam usia 62 tahun kurang 13 hari. ${ }^{24}$

2. Adam (wafat tahun $220 \mathrm{H}$ )

Nama lengkapnya adalah Adam bin Abi Iyas. Beliau termasuk tabiit tabiin (ketemu tabiin). Nama panggilannya (kuniah) adalah Abul Hasan. Beliau bertempat tinggal di Bagdad dan meninggal pada tahun 220 H. Diantara Guru gurunya adalah Muhammad bin Abdir Rahman bin Mughiroh bin Harist bin Abi Dzi'bin(Abu Harits), Isroil bin Yunus bin Abi Ishak, Hafs bin Muyasyaroh, Salam bin Miskin bin Robi'ah, sulaiman bin Mughiroh, Su'bah bin Hujaj, Syaiban bin Abdir

${ }^{24}$ Hadis 9 Imam dan terjemahannya CD 
Rahman, Isya bin Maimun,lais bin Sa'ad bin abdir Rahman, warqo bin Umar. Diantara murid - muridnya adalah Ahmad bin Al Azhar, Abdullah bin Abdurrahman, Amr bin Manshur, Muhammad bin Ismail, Muhammad bin Holaf dan lain - lain.

Penilaian para ulama tentang beliau menurut yahya bin Muin beliau menilai siqah,Abu Hatim Ar-Rozi menilai siqah makmun, An - Nasai menilai Labaksa bih,Al Ijali menilai siqah dan Abu Daud menilai siqat.

3. Ibnu Abi Dzi'bin (Wafat $158 \mathrm{H}$ )

Nama lengkapnya adalah Muhammad bin Abdir Rahman bin Mughiroh bin Harist bin Abi Dzi'bin. Beliau termasuk tabiit tabiin senior. Nama panggilannya (kuniah) adalah Abu Harist. Beliau bertempat tinggal di Madinah dan meninggal pada tahun $158 \mathrm{H}$.

Di antara guru - gurunya Muhammad bin Muslim bin 'Ubaidillâh bin 'Abdillâh bin Syihâb bin 'Abdillâh bin al-Hârith bin Zuhrah bin Kilâb bin Murrah al-Quraisyi az-Zuhri alMadani(Az - Zuhri), Muhammad bin Qois, Abul Mu'tamar bin Amr bin Rofi', Ishak bin Yazid, Al Aswad bin 'ala, Harist bin Abdir Rahman, Sa'id bin Abi Sa'id, Sa'id bin Kholid bin Abdillah, Syu'bah bin dinar, Sholeh bin Abdi Hisan, Abdur Rahman bin sa'd, dan lain - lain.

Di antara murid - muridnya adalah Adam bin Abi Iyas, Abu Bakar bin 'Tyas bin Salim,Ahmad bin Abdillah bin Yunus, Ishak bin Sulaiman, Ishak bin Muhammad bin Abdir Rahman, Asad bin Musa, Ismail bin Umar, Husain bin Muhammad bin Bahrom, Hamad bin kholid, Kholid bin Haris, Dawud bin Atho, dan lain - lain. 
Penilaian para ulama tentang beliau, menurut Ahmad bin Hambal menilai siqah suduq, Yahya bin Mu'in menilai siqah,An Nasai menilai siqah,Ya'kub bin Syaibah menilai siqah suduq,Ibnu Hibban menilai siqah dan Al Kholal menilai siqah.

4. Az-Zuhri (Wafat $124 \mathrm{H}$ )

Nama lengkapnya adalah Muhammad bin Muslim bin 'Ubaidillâh bin 'Abdillâh bin Syihâb bin 'Abdillâh bin al-Hârith bin Zuhrah bin Kilâb bin Murrah al-Quraisyi al-Zuhri alMadani. Beliau adalah seorang atbiin dan beliau adalah salah seorang Imam dan ulama Hijaz dan Syam. Beliau bertempat tinggal di Madinah dan beliau meninggal pada tahun $124 \mathrm{H}$.

Guru - gurunya antara lain adalah 'Abdullâh bin 'Abd al-Rahmân bin 'Auf az-Zuhri,'Abdullâh bin 'Umar bin alKhaththâb, 'Abdullâh bin Ja'far, Rabî'ah bin 'Abbâd, alMismar bin Makhramah, Anas, Jâbir, 'Abdullâh bin 'Âmir bin Rabî’ah, Abû al-Thufail, dan lain-lain.

Murid -muridnya di antaranya adalah 'Athâ' bin Abi Rabâh, Abu al-Zubair al-Makki, 'Umar bin 'Abd al-'Azîz, 'Amr bin Dînar, al-Auza'i, Shâlih bin Kaisân, Yunus bin Yazid, Ma'mar, al-Zubaidi, dan lain-lain.

Penilaian para ulama tentang beliau, menurut Ayyub As- Sa'tiyani menilai saya tidak melihat seorangpun lebih 'alim daripadanya,Musa bin Ismail menilai tidak ada orang yang lebih faham tentang sunnah daripadanya,Amr bin Dinar menilai saya tidak melihat seorangpun lebih fasih tentang hadis daripada $\mathrm{Az}-\mathrm{Zuhri}$ 
5. Abu Salamah ( Wafat $94 \mathrm{H}$ )

Nama lengkapnya adalah 'Abdullâh bin 'Abd alRahmân bin 'Auf al-Zuhri. Ia termasuk salah seorang tabi'in. Nama panggilannya (kuniah) adalah Abu Salamah, beliau menetap dan meninggal di Madinah pada tahun $94 \mathrm{H}$.

Guru - guru Abû Salamah antara lain 'Abd al-Rahman bin Shakhr al-Dausi al-Yamani(Abu Hurairah), Ibrahim bin 'Abdullâh bin Qâridl, Abu al-Radâd, Abu Sufyân bin Sa'îd bin Mughîrah, Usâmah bin Zaid bin Hâritsah, Abû Hurairah, dan lain-lain.

Murid - murid Abû Salamah antara lain adalah Ibrâhîm bin 'Ablah Syamr bin Yaqdlân, Ibrâhîm Sa'ad bin Ibrâhîm, Ismail bin Umayyah, Muhammad bin Muslim bin Syihâb al-Zuhri, dan lain-lain.

Penilaian para ulama tentang beliau,menurut Abu Zar'ah Ar - Rozi menilai siqah imam,Ibnu Hiban menilai siqah dan Adzahabi menilai Ahadul Aimmah (salah satu imam hadis).

6. Ahmad bin Hambal (Wafat $241 \mathrm{H}$ )

Nama lengkapnya adalah Ahmad bin Muhamad bin Hanbal bin Hilal bin Asad bin Idris bin Abdullah bin Hayyan bin Abdullah bin Anas bin 'Auf bin Qasithi bin Marin bin Syaiban bin Dzuhl bin Tsa'labah bin Uqbah bin Sha'ab bin Ali bin Bakar bin Wail. Nama panggilannya/Kuniyah adalah Abu Abdillah Nasab beliau, Bapak dan ibu beliau adalah orang arab, keduanya anak Syaiban bin Dzuhl bin Tsa'labah, seorang arab asli. Bahkan nasab beliau bertemu dengan Nabi shallallahu 'alaihi wa sallam di Nazar. Kelahiran beliau: Imam Ahmad dilahirkan di kota Baghdad. Ada yang berpendapat 
bahwa di Marwa, kemudian di bawa ke Baghdad ketika beliau masih dalam penyusuan. Hari lahir beliau pada tanggal dua puluh Rabi'ul awwal tahun 164 hijriah dan beliau meninggal pada tahun $241 \mathrm{H}$.

Permulaan imam Ahmad dalam rangka menuntut ilmu pada tahun $179 \mathrm{H}$, pada saat itu beliau berusia empat belas tahun. Setamatnya menghafal Alquran dan mempelajari ilmuilmu bahasa Arab di al-Kuttab saat berumur 14 tahun, beliau melanjutkan pendidikannya ke ad-Diwan. Beliau terus menuntut ilmu dengan penuh semangat yang tinggi dan tidak mudah putus asa.

Keteguhan dalam mencari ilmu telah mengantarkan imam Ahmad menjadi ulama besar dan disegani, baik dari kalangan masyarakat awwam, terpelajar maupun dari kalangan penguasa. Diantara guru - gurunya adalah Waqi' bin Al Jarrah bin Malih, Husyaim bin Basyir, Sufyan bin Uyainah ,Ibrahim bin Sa'ad ,Yahya bin Sa'id al QaththÃ $f$ Â\&n ,WalÃ $f \hat{A} \circledast d$ bin Muslim ,Ismail bin 'Ulaiyah ,Al Imam Asy Syafi'i ,Al Qadli Abu Yusuf, Ali bin Hasyim bin al Barid, Mu'tamar bin Sulaiman dan lain - lain. Sedangkan murid muridnya adalah Abdurrazzaq,Abdurrahman bin Mahdi, Al Imam Asy Syafi'I,Yahya bin Adam,Al Hasan bin Musa al Asyyab.

Penilain para ulama tentang beliau, menurut :

a. Qutaibah menuturkan; sebaik-baik penduduk pada zaman kita adalah Ibnu Al Mubarak, kemudian pemuda ini (Ahmad bin Hambal), dan apabila kamu melihat seseorang mencintai Ahmad, maka ketahuilah bahwa dia adalah pengikut sunnah. Sekiranya dia berbarengan dengan masa 
Ats Tsauri dan al Auza'I serta Al Laits, niscaya Ahmad akan lebih di dahulukan ketimbang mereka.

b. Asy Syafi'i menuturkan; aku melihat seorang pemuda di Baghdad, apabila dia berkata; 'telah meriwayatkan kepada kami,' maka orang-orang semuanya berkata; 'dia benar'. Maka ditanakanlah kepadanya; 'siapakah dia?' dia menjawab; 'Ahmad bin Hambal.'

c. Ali bin Al Madini menuturkan; sesungghunya Allah memuliakan agama ini dengan perantaraan Abu Bakar pada saat timbul fitnah murtad, dan dengan perantaraan Ahmad bin Hambal pada saat fitnah Al qur`an makhluk. ${ }^{25}$

7. Waqi' ( Wafat $196 \mathrm{H}$ )

Nama lengkapnya adalah Waqi' bin Jarrah bin malih, beliau adalah seorang tabiit tabiin. Nama panggilannya/ kuniah adalah Abu Sofyan. Beliau tinggal di Kuffah dan meninggal pada tahun $196 \mathrm{H}$.

Di antara guru - gurunya adalah Sulaiman bin Mughiran (A'mas), Aban bin Yazid, Ibrahim bin Ismail bin Mujma' bin Yazid, Ibrahim bin Fadhil, Idris bin Yazid bin Abdur Rahman, Usamah bin Zaid, Ismail bin Yunus bin Abi Ishak, Ismail bin Abi Khalid dan lain - lain. Sedangkan Murid - muridnya adalah Ishak bin Ismail, Sulaiman bin Dawud, Muhammad bin Abdullah bin Namir, Yahya bin Mu'in bin 'Aun dan lain - lain.

Penilaian para ulama tentang beliau menurut Ahmad bin Hanbal berkomentar Saya tidak melihat orang lebih hafidz melebihi beliau,Yahya bin Mu'in beliau memuji Saya tidak melihat orang lebih hafidz dari beliau,Al'ijli menuturkan bahwa

${ }^{25}$ Hadis 9 Imam dan terjemahannya CD 
Rubini : Hadits Tarbawi Tentang Potensi Anak (Fitrah)

beliau adalah siqah hafidz hadis dan Ya'kub bin Syaibah menilai Hafidz

8. A'mas (Wafat $147 \mathrm{H}$ )

Nama lengkapnya adalah Sulaiman bin Maghron, beliau adalah seorang tabiit tabiin. Nama panggilannya/ kuniah adalah Abu Muhammad. Beliau bertempat tinggal di Kuffah dan meninggal dunia (Wafat) tahun $147 \mathrm{H}$.

Di antara guru - gurunya adalah Dzaqun(Abu Shalih), Ibrahim bin Yazid bin sarik, Ibrahim bin Yazid bin Qis, Ishaq bin Murar, ismail bin Abi Khalid, Tamim bin Salamah, Tsabit bin 'Abid dan lain - lain. Sedangkan murid - muridnya adalah Hafish bin Ghiyas bin Tholaq, Abu Bakar bin 'iyas bin Salim, Israil bin Yunus bin Abi Ishak dan lain - lain.

Penilaian para ulama tentang beliau, menurut Yahya bin Mu'in menilai siqah, Al 'ajli menilai siqah tsabit dan Abu Khatan Ar Rozi menilai siqah yahtaju bi hadis.

9. Abu Shalih (Wafat $101 \mathrm{H}$ )

Nama lengkapnya adalah Dzaqwan, beliau adalah seorang tabiin, Nama panggilannya/kuniyah adalah Abu Shalih, beliau tinggal di Madinah dan wafat pada tahun 101 H.

Di antara guru - gurunya adalah Abdur Rahman bin Sahir (Abu Hurairah), Romlah binti Abi Sofyan, Sahir bin Khalid bin umait, Zaid bin Khalid, Sa'id bin Thorif, Aisyah binti Abu Bakar dan lain - lain. Sedangkan murid - muridnya adalah Waqi' bin Jarrah bin Malih, Zaid bin Aslam, Abu Bakar bin Iyas, Jarir bin Abdul Hamid bin Qirtho dan lain - lain.

Penilaian para ulama terhadap beliau adalah sebagai berikut. menurut Ahmad bin Hambal menilai beliau adalah 
Tsiqoh-tsiqoh,Yahya bin Mu'in menilai beliau adalah Tsiqah, Abu Hatim Ar Razi menilai beliau adalah Tsiqoh, Sholih, wayuhtaju bihi, Muhammad bin Sa'id menilai beliau adalah Tsiqoh, dan As-Saji menilai beliau adalah Tsiqoh Shoduq

10. Abu Hurairah (Wafat $57 \mathrm{H}$ )

Nama lengkapnya adalah 'Abdur -Rahman bin Shakhr al-Dausi al-Yamani. Beliau bertempat tinggal di Madinah, beliau kemudian diberi gelar Abu Hurairah oleh Nabi saw, karena kecintaannya pada kucing. Beliau termasuk salah seorang sahabat yang paling banyak meriwayatkan hadis, yang menurut Imam al-Bukhari 800 orang sahabat dan tabi'in meriwayatkan hadis darinya. Menurut penuturan al-Haitsam bin 'Ady, beliau meninggal pada tahun $57 \mathrm{H}$. Sedangkan menurut al-Waqidi, Beliau meninggal dunia pada tahun $59 \mathrm{H}$.

Menurut kaidah umum dalam ilmu hadis, al-shahabah kulluhum'udul, maka dia dimasukkan kedalamnya yang berarti keadilan dan kedhabith-annya dapat diterima. ${ }^{26}$

Berdasarkan riwayat hidup/biografi para rawi tersebut di atas, maka hadis tersebut dikategorikan sebagai hadis yang sahih dengan alasan :

a. Sanadnya bersambung

Hal ini dapat diketahui dari ketersambungan antara periwayat satu dengan yang lainnya atau adanya hubungan guru dan murid.

b. Seluruh perawi dalam sanad tersebut bersifat adil dan dhabith.

Hal ini diketahui dari penilaian para ulama terhadap para rawi. Tidak ada satupun yang mencela.

${ }^{26}$ Kutubut Tis'ah, CD room 
Rubini : Hadits Tarbawi Tentang Potensi Anak (Fitrah)

c. Dalam sanad tersebut terhindar dari Syudzudz (kejanggalan) dan 'illat(cacat)

Kesahihah sanad (shahîh al-Isnâd) belum menjadi jaminan bagi kesahihan matan (shahîh al-matn). Sebuah hadis yang sanadnya sahih muttasil dapat saja memiliki matan yang tidak sahih, dan demikian juga sebaliknya. Penelitian kedua aspek (sanad dan matan) menjadi penting untuk menemukan validitas dan otentisitas sebuah hadis.

Jika hadis tentang fitrah ini dicermati, maka terdapat perbedaan redaksi atau kalimat yang digunakan oleh masingmasing periwayat. Dan perbedaan redaksinya

Redaksi Al-Bukhari

$$
\text { كل مولود يولا على الفطرة }
$$

Redaksi Ahmad bin Hambal

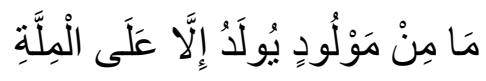

Al-Bukhari pada hadis yang dijadikan titik tolak kajian dalam buku ini menggunakan kalimat kullu maulûd yûlad dan al - fitrah, sedangkan Ahmad bin Hambal menggunakan kalimat yang berbeda redaksi mâ min maulûd yuladu illâ dan menggunakan kata al-millah.

Perbedaan redaksi atau lafal yang demikian merupakan sesuatu yang wajar dalam periwayatan hadis, karena kebanyakan periwayatan hadis dilakukan secara makna (al-riwâyah bil-ma'na). Oleh sebab itu, perbedaan lafal menjadi sesuatu yang tidak dapat dihindari dalam periwayatan hadis. Perbedaan lafal dalam hadis tentang fitrah tidak terjadi syudzudz (janggal) dan illah (cacat).

Dengan demikian dapat dikatakan bahwa hadis-hadis tentang fitrah tersebut dari segi sanad dan matan dapat dijadikan 
sebagai hujjah (pegangan) bagi ajaran Islam, karena sanadnya bersambung (muttasil) dan matannya tidak mengandung unsur janggal dan cacat.

Kebanyakan para pensyarah hadis mengkaitkan pemaknaan fitrah dalam hadis dengan penafsiran fitrah dalam alQur'an. Ibnu 'Abd al-Barr, seorang ahli hadis, sebagaimana dinukil oleh al-Mubârakfuri, ketika mensyarahi hadis: كل مولود يولد , على الفطرة beliau menyatakan bahwa kata fitrah yang dimaksud adalah Islam. Arti ini berlaku pula pada umumnya di kalangan ulama salaf.

Fitrah menurut kamus bahasa Arab secara lughowi adalah bermaksud " sifat yang disifati dengannya terhadap segala wujud pada awal kejadiannya". Dengan kata lain disebut sifat dasar manusia. ${ }^{27}$ Menurut kamus bahasa indonesia fitrah berasal dari sifat asal, kesucian, bakat, Pembawaan. ${ }^{28}$

Secara terminologi dapat diartikan dalam surat ar-Rum(30) ayat 30 .

Maka hadapkanlah wajahmu dengan Lurus kepada agama Allah; (tetaplah atas) fitrah Allah yang telah menciptakan manusia menurut fitrah itu. tidak ada peubahan pada fitrah Allah. (Itulah) agama yang lurus; tetapi kebanyakan manusia tidak mengetahui[1168],

Fitrah Allah: Maksudnya ciptaan Allah. manusia diciptakan Allah mempunyai naluri beragama Yaitu agama tauhid. kalau ada manusia tidak beragama tauhid, Maka hal itu tidaklah wajar.

27 Warul Walidin, Konstelasi pemikiran paedagogik ibnu khaldun perspektif pendidikan modern, (Yogyakarta : Nadiya Foundation,2003), hlm. 96

28 Hasan Alwi dkk. Kamus besar bahasa Indonesia, (Jakarta: Balai Pustaka,2005), hlm. 318 


\section{Rubini : Hadits Tarbawi Tentang Potensi Anak (Fitrah)}

mereka tidak beragama tauhid itu hanyalah lantara pengaruh lingkungan.

Para ahli tafsir sepakat untuk mentakwilkan kata fitrah dengan surat dalam Al - Qur'an surat Ar-Rum (30) :30 dengan arti Islam karena beberapa alasan yaitu :

1. Abu Hurairah ketika meriwayatkan hadis tentang fitrah tersebut mencantumkan pesan dia dengan ziyâdah pada akhir matan hadis "jika kamu menghendaki maksud kata fitrah itu, maka rujuklah kepada Q.S. Ar-Rum (30) ayat 30.

2. Kata al-millah dalam riwayat Ahmad bin hambal yang diartikan sama dengan fitrah (agama Islam).

خلق yang artinya mencipta. Biasanya ketiga kata tersebut digunakan dalam al Qur'an untuk menunjukan pengertian sesuatu yang sebelumnya belum ada dan masih merupakan pola dasar yang perlu penyempurnaan.

Quraish Shihab dalam tafsir al - Misbah, fitrah merupakan "menciptakan sesuatu pertama kali/tanpa ada contoh sebelumnya". Dengan mengikut sertakan pandangan Quraish sh tersebut berarti fitrah sebagai unsur, sistem dan tata kerja yang diciptakan allah pada makhluknya sejak awal kejadian sehingga menjadi bawaannya. Inilah yang disebut oleh beliau dengan arti asal kejadian atau bawaan sejak lahir 29

Ibnu Kaldun memakai fitrah sebagai potensi - potensi laten yang akan bertransformasi menjadi aktual setelah mendapat rangsangan dari luar. Dikatakannya jiwa apabila dalam fitrahnya

${ }^{29}$ Quraish shihab, tafsir al misbah;pesan, kesan dan keserasian al Qur'an, Vol 11(Jakarta : lentera hati,2002), hlm. 53

44 Jurnal Komunikasi dan Pendidikan Islam, Volume 4, Nomor 2, Desember 2015 
yang semula siap menerima kebaikan dan kejahatan yang datang dan melekat padanya. ${ }^{30}$

Dengan demikian dapat dipahami bahwa fitrah adalah suatu keadaan (yaitu agama Islam) dalam diri manusia yang telah diciptakan oleh Allah sejak manusia itu dilahirkan. Esensi dari agama Islam tersebut adalah tauhid.

Tauhid merupakan suatu kepercayaan tentang Tuhan dengan segala aspeknya, seperti soal wujud-Nya, keesaan-Nya, sifat-sifat-Nya; yang berhubungan dengan alam semesta seperti terjadinya alam semesta, keadilan dan kebijaksanaan Tuhan, qadâ' dan qadar; yang berhubungan dengan keutusan para Rasul, alam ghaib, kitab-kitabnya dan lain-lain. Dasar dari adanya fitrah tersebut adalah pengakuan roh manusia sewaktu diciptakan. Dalam aspek tauhid, semua agama samawi sejak Nabi Adam as sampai penutup Nabi, Muhammad saw adalah sama. Perbedaannya hanya pada aspek syari'atnya/mekanisme operasional aturan untuk mendekatkan diri pada Tuhan. ${ }^{31}$

Secara prinsip, tidak terjadi silang pendapat di kalangan ulama mengenai pengertian fitrah; apakah diartikan dengan agama samawi (hanif), Islam atau tauhid. Agama samawi dan Islam adalah agama yang pokok ajarannya berupa tauhid. Ini berarti memiliki kesamaan agama-agama samawi sebelumnya. Dengan kata lain bahwa percaya kepada Tuhan dan merasa memerlukan-Nya merupakan fitrah setiap manusia.

Oleh karena ajaran tauhid itu sesuai dengan petunjuk akal, maka akal akan membimbing fitrah. Jiwa manusia diibaratkan seperti lembaran putih bersih yang siap menerima

30 Ibid, warul walidin, hlm. 96

31 http://erlanmuliadi.blogspot.com/2010/12/studi-al-hadits-fitrahmanusia.html 


\section{Rubini : Hadits Tarbawi Tentang Potensi Anak (Fitrah)}

tulisan apapun. Ia juga seperti lahan yang dapat ditanami tumbuhan apapun. Jiwa manusia menyerap berbagai agama dan pengetahuan, akan tetapi yang diserap adalah hal-hal yang baik. Jiwa manusia tidak akan mengubah atau mengganti fitrah tersebut dengan berbagai pendapat yang merusak, tetapi hal itu tentu ada guru yang mengajarinya ke arah yang rusak itu. Andaikata anak itu dibiarkan tumbuh dan berkembang tanpa ada pengaruh luar, maka anak akan tahu dengan sendirinya bahwa Tuhan itu Esa, dan akalnya akan menetapkan demikian. Ia menganalogikan hal itu dengan hewan yang lahir dalam keadaan terpotong telinganya atau bagian tubuh lainnya, kecuali karena faktor luar.

Ahmad Tafsir mengemukakan pendapat bahwa fitrah adalah potensi-potensi untuk menjadi baik dan sekaligus menjadi buruk, potensi untuk menjadi muslim dan untuk menjadi musyrik. Secara sederhana, fitrah di sini diartikan dengan potensi untuk beragama, juga potensi untuk tidak beragama ${ }^{32}$. Penafsiran fitrah dengan arti potensi akan lebih tepat jika yang dimaksudkan adalah potensi-potensi internal manusia seperti: akal, ruh, nafs, qalb, fuâd dan lain-lain. Potensi-potensi tersebut disebut dengan fithrah munazzalah, yaitu potensi-potensi atau kesiapan yang masih bersih tanpa goresan apapun yang perkembangannya sangat bergantung kepada faktor luar terutama sumberdaya pendidikan. Perkembangan fithrah khalqiyyah sangat bergantung kepada pengembangan fithrah munazzalah.

Sesuai dengan konsep Islam yang memandang manusia sebagai manusia, bukan sebagai binatang karena manusia

32 H.A.Tafsir, Filsafat Pendidikan Islam, (Bandung;Pustaka Setia;2009), hlm. 203

46 Jurnal Komunikasi dan Pendidikan Islam, Volume 4, Nomor 2, Desember 2015 
memiliki derajat yang tinggi, bertanggung jawab atas segala yang diperbuat, serta makhluk yang memikul amanat berat. Apapun perbuatan dan karakteristik manusia tetap dihargai sebagai manusia, bukan diidentikkan sebagai hewan. ${ }^{33}$ Ini merupakan penegasan dari firman Allah yang berbunyi:

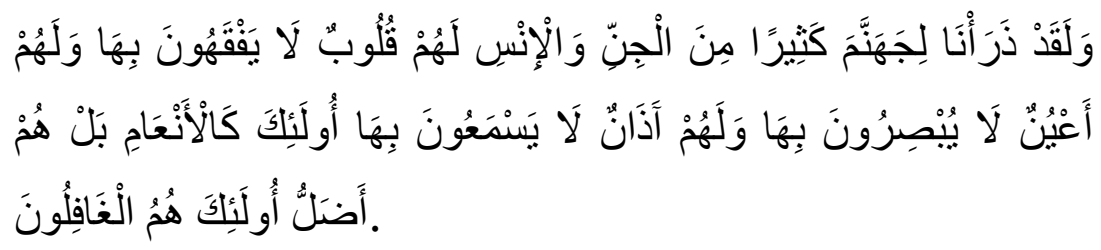

Dan sesungguhnya Kami jadikan untuk isi neraka Jahannam kebanyakan dari jin dan manusia, mereka mempunyai hati, tetapi tidak dipergunakannya untuk memahami (ayat-ayat Allah) dan mereka mempunyai mata tetapi tidak dipergunakannya untuk melihat dan mereka mempunyai telinga tetapi tidak dipergunakan untuk mendengar. Mereka itu seperti binatang ternak, bahkan lebih sesat lagi. Mereka itulah orang-orang yang lalai. [QS. Al-A'raf (7):179].

Sementara itu, perkembangan diri manusia, baik imanitas maupun humanitas sangat dipengaruhi oleh beberapa faktor yang oleh M.J. Langeveld diklasifikasi ke dalam 4 faktor pengaruh, yaitu:

1. Faktor pengaruh dari pembawaan,

2. Faktor pengaruh dari lingkungan sekitar

3. Faktor emansipasi (kehendak untuk bebas dari orang lain) serta

33 Hadari Nawawi, Hakekat manusia menurut islam, (Surabaya : Al ikhlas , 1993), hlm. 23 
4. Faktor dari usaha eksplorasi (penjelajahan terhadap keadaan dunia sekitar). 34

Hadis di atas (yang diriwayatkan oleh Al Bukhari dan Ahmad bin Hambal) menunjukan bahwa fitrah adalah potensi baik. Sebab pengertian menjadi yahudi bermakna menyesatkannya. Artinya orang tua yang menjadikan perkembangannnya menyimpang dari sifat dasar yang membawa fitrah ketauhidan dan sepatutnya berkembang ke arah yang baik.

Tegasnya hadis tersebut mengeksplisitkan bahwa fitrah yang yang dibawa lahir itu sangat besar dipengaruhi oleh faktor lingkungan yang mungkin dapat mengubah secara drastis fitrah itu. Ada kalanya lingkungan bisa membuat baik atau sebaliknya. Walaupun seorang anak mempunyai pembawaan (beragama tauhid) namun pembawaan itu tidak maha kuasa menentukan perkembangan baik.

Hadis diatas memberi kemungkinan kepada orang tua / lingkungan mempengaruhi perkembangannya ${ }^{35}$. Salah satu bagian dari lingkungan adalah pendidikan. Pendidikan sangat mempengaruhi perkembangan dari setiap manusia. Orang tua mempunyai tanggung jawab kepad anaknya berkembang sesuai fitrahnya, bertanggung jawab terhadap pendidikan anaknya.

Sehubungan tanggung jawab di atas, sebaiknya orang tua dapat menentukan cara mendidik anaknya. Semua orang menginginkan anak yang sholeh dan sholehah yaitu anak yang

34 I.R. Poegjawijatna, Manusia dengan Alamnya, (Jakarta : Bina Aksara, 1983), hlm. 51

35 Muh. Anis, Jurnal Kependidikan Islam; pendidikan Islam dan tantangan multicultural, (Yogyakarta: tarbiyah UIN Suka,2008), hlm. 74 
beriman, bertaqwa kepada allah SWT, berbakti kepada orang tua, anak yang cerdas, sehat, kuat, dan berakhlak terpuji36.

Untuk mencapai tujuan tersebut, peran utama menjadi pendidik adalah orang tua. Menurut Ahmad Tafsir, kaidah ini ditetapkan secara kodrati, artinya orang tua tidak dapat berbuat lain. Mereka harus menempati posisi itu dalam keadaan bagaimanapun karena mereka ditakdirkan menjadi orang tua dari anak yang dilahirkannya. Oleh karena itu, mau tidak mau mereka harus menjadi pendidik utama dan pertama. ${ }^{37}$

Setiap orang tua harus memahami hakekat anak sebagai yang dikenai pendidikan. Beberapa hal yang perlu difahami adalah :

1. Anak mempunyai dunia sendiri sehingga anak tidak diperkenankan disamakan dengan orang dewasa (perlakuannya).

2. Anak mempunyai periode dan perkembangan tertentu dan mempunyai pola perkembangan serta tempo dan iramanya.

3. Anak memiliki kebutuhan dan menuntut untuk memenuhi kebutuhan itu semaksimal mungkin. Kebutuhan anak menurut Maslow, mencakup kebutuhan biologis, rasa aman, rasa kasih sayang, rasa harga diri, dan realisasi diri.

4. Anak memiliki perbedaan antara individu dengan individu yang lain.

5. Anak dipandang sebagai kesatuan sistem manusia. Sesuai dengan hakekat manusia.

36 Prof. Dr.H.A.Tafsir, Filsafat Pendidikan Islam, (Bandung;Pustaka Setia;2009, )hlm. 203

37 Ahmad Tafsir, Filsafat Umum, (Bandung ;Rosdakarya;2007), hlm. 155 
6. Anak merupakan objek pendidikan yang aktif dan kreatif serta produktif 38 .

Dari beberapa hal yang perlu difahami orang tua tentang anak, maka langkah pendidikan yang tepat harus ditempuh oleh orang tua (lihat surat Luqman ayat $15-19$ ) adalah :

1. Pendidikan Ketauhidan

Orang tua mempunyai kewajiban membimbing anaknya dalam berketuhanan yaitu bertuhan kepada Allah SWT.

2. Pendidikan Akhlaq

Pendidikan akhlaq anak dalam Al - Qur'an bertumpu pada aspek fitrah yang terdapat di dalam diri manusia, sesuai dalam hadis berikut: Pendidikan akhlaq perlu dilakukan dengan cara sebagai berikut :

a. Menumbuhkan motivasi dalam diri anak yang bersumber pada iman dan taqwa.

b. Meningkatkan pengetahuan anak tentang akhlaq Al Qur'an lewat pengetahuan, pengalaman dan latihan.

حق الولد على والده ان يحسن اسمه ويحسن موضعه ويحسن أدبه (رواه البيهقي عن عائشة)

Artinya: Kewajiban orang tua terhadap anaknya adalah memberi nama yang baik, memberi tempat tinggal yang baik, dan mengajari sopan santun.

c. Melakukan pembiasaan yang baik sehingga perbuatan yang baik menjadi keharusan moral dan akan tumbuh dalam diri anak sejak dini ${ }^{39}$.

38 Ibid, hlm. 204

39 Mahmud Miharso, M.SI, Pendidikan Keluarga Qur'ani(Safiria Insania press, Bandung:2000)hlm 123 
3. Pendidikan Sholat

Melakukan sholat lima waktu adalah salah satu tanda utama kepatuhan kepada Allah SWT. Ketika anak sudah melakukan sholat dengan benar dan baik, maka amalan - alaman yang lain dengan sendiri akan baik.

Hadis yang berkaitan dengan pendidikan sholat adalah ;

$$
\begin{aligned}
& \text { علموا الصيى الصلاة ابن سبع سنين واضربوه عليها ابن عشر (رواه }
\end{aligned}
$$

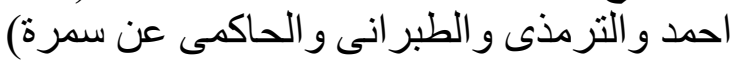

Artinya: Ajarilah anak sholat ketika umur 7 tahun, dan pukulah jika meninggalkannya dalam umur 10 tahun. (HR. Ahmad, Turmudhi, Tabarani, dan Hakim dari Samirah).

Hadis lain yang berkaitan dengan pendidikan sholat adalah

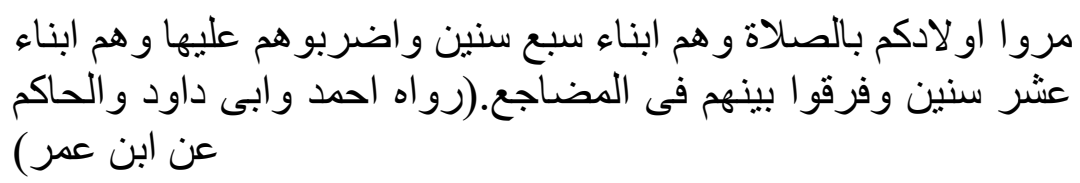

Artinya: Perintahlah anakmu sholat pada usia tujuh tahun, dan pukulah jika meninggalkannya pada usia sepuluh tahun, dan pisahkanlah tempat tidurnya (HR. Ahmad dan Abi Daud dan Hakim dari Ibn 'Umar) ${ }^{40}$

4. Pendidikan Amar Ma'ruf nahi Mungkar

Orang tua mempunyai tugas yang sangat mulia untuk mengajak anak-anaknya berbuat baik di setiap saat dan menghindari larangan Allah SWT

5. Pendidikan ketabahan dan kesabaran 41

Berdasarkan keterangan di atas, dapat dikatakan bahwa Fitrah adalah potensi baik, orang tua yang menjadikan hlm . 207

40 Kutubut tis'ah

41 A.Tafsir, Filsafat Pendidikan Islam, (Bandung;Pustaka Setia;2009), 
Rubini : Hadits Tarbawi Tentang Potensi Anak (Fitrah)

perkembangannnya menyimpang dari sifat dasar dan sepatutnya berkembang ke arah yang baik. Fitrah yang yang dibawa lahir itu sangat besar dipengaruhi oleh faktor lingkungan yang mungkin dapat mengubah secara drastis fitrah itu. Pendidikan sangat mempengaruhi perkembangan dari setiap manusia. Orang tua mempunyai tanggung jawab kepada anaknya berkembang sesuai fitrahnya, bertanggung jawab terhadap pendidikan anaknya. Langkah pendidikan yang tepat harus ditempuh oleh orang tua adalah pendidikan ketauhidan, pendidikan Akhlaq, pendidikan Sholat, pendidikan Amar Ma'ruf nahi mungkar, pendidikan ketabahan dan kesabaran.

\section{Penutup}

Dua hadits yang tentang fitrah yang diriwayatkan oleh Imam Bukhari dan Imam Ahmad bin Hanbal adalah merupakan hadits yang shahih. Karena telah memenuhi syarat - syarat keshahihan suatu hadis yaitu Sanadnya bersambung, Seluruh perawi dalam sanad tersebut bersifat adil dan dhabith, dalam sanad tersebut terhindar dari Syudzudz (kejanggalan) dan 'illat (cacat).

Fitrah adalah potensi-potensi untuk menjadi baik dan sekaligus menjadi buruk, potensi untuk menjadi muslim dan untuk menjadi musyrik. Secara sederhana, fitrah di sini diartikan dengan potensi untuk beragama, juga potensi untuk tidak beragama. Pendidikan merupakan media untuk mempertahankan fithrah khalqiyyah dan sarana untuk mengasah dan menumbuhkembangkan fithrah munazzalah sehingga mampu mengimplementasikan keberagaman dan moralitas yang baik. 
Orang tua mempunyai tanggung jawab kepada anaknya berkembang sesuai fitrahnya, bertanggung jawab terhadap pendidikan anaknya. Langkah pendidikan yang tepat harus ditempuh oleh orang tua adalah pendidikan ketauhidan, pendidikan Akhlaq, pendidikan Sholat, pendidikan Amar Ma'ruf nahi mungkar, pendidikan ketabahan dan kesabaran. 


\section{DAFTAR PUSTAKA}

A.Tafsir, Filsafat Pendidikan Islam, (Bandung: Pustaka Setia, 2009)

Fuad Nashori, Potensi -Potensi Manusia, (Yogyakarta: Pustaka Pelajar, 2005)

Hadari Nawawi, Hakekat Manusia Menurut Islam, (Surabaya : Al Ikhlas, 1993)

Hadari Nawawi, Hakekat Manusia Menurut Islam, (Surabaya: Al Ikhlas, 1993)

Hadis 9 Imam dan terjemahannya CD room

http: / / erlanmuliadi.blogspot.com/2010/12/studi-al-hadits-fitrahmanusia.html

I.R. Poedjowijatma, Manusia Dengan Alamnya (Filsafat Manusia), (Jakarta: Bina Aksara, 1983)

Juwariyah, Hadits Tarbawi, (Yogyakarta: Teras, 2010)

Kutubut Tis'ah, CD room

Mahmud Miharso, M.SI, Pendidikan Keluarga Qur'ani, (Bandung: Safiria Insania Press: 2000)

Muh. Anis, Jurnal Kependidikan Islam; Pendidikan Islam dan Tantangan Multicultural, (Yogyakarta: Tarbiyah UIN Suka, 2008)

Quraish Shihab, Tafsir Al Misbah; Pesan, Kesan dan Keserasian Al-Qur'an, Vol.11(Jakarta : Lentera Hati, 2002) 